\title{
Warunki owocnego uczestnictwa dzieci we mszy świętej. Perspektywa psychologiczna
}

Punktem wyjścia rozważań psychologa na temat formy i treści mszy dla dzieci jest zdefiniowanie samego terminu „dziecko”. W psychologii rozwojowej wymienia się trzy fazy dzieciństwa wczesne: od urodzenia do lat trzech; średnie: od czterech do sześciu lat; późne: od siedmiu do dziesięciu lat. Należałoby więc wskazać właściwości charakteryzujące rozwój dzieci w poszczególnych okresach. Te właściwości wieku odnoszą się zarówno do rozwoju fizycznego, jak i poznawczego, społecznego oraz emocjonalnego. Nie wydaje się konieczne przytaczanie szczegółowych informacji o cechach rozwojowych. Warto jednakże wskazać na te z nich, o których dorośli (rodzice, opiekunowie, nauczyciele i księża) powinni wiedzieć. We wczesnym dzieciństwie rodzi się autonomia, kształtują się sprawności motoryczne i komunikacyjne dziecka. Rola dorosłych sprowadza się do uwzględniania w swych zachowaniach sposobu, w jaki dzieci rozumieją konkretną sytuację, w której się znalazły, a nie

\footnotetext{
1 Doktor, psycholog, wieloletni pracownik naukowo-dydaktyczny w Instytucie Psychologii UJ, obecnie pracownik Uniwersytetu Papieskiego Jana Pawła II w Krakowie. Autorka kilkudziesięciu prac naukowych z rozwoju mowy i myślenia dziecka oraz zagadnień związanych z uwarunkowaniami procesu wychowania w rodzinie (wligeza@pk.edu.pl).
} 
tylko egzekwowania wykonania poleceń. Jednocześnie dorośli muszą uwzględniać pragnienia dzieci, aby podtrzymywać ich chęć do działania, uczenia się; muszą pamiętać, że są modelem dla powstającego wzoru samodzielności i samoregulacji zachowań dziecka. W średnim dzieciństwie dominującą cechą rozwojową jest ciekawość poznawcza wyrażająca się przede wszystkim w pytaniach. Kluczowa funkcja rodziców i opiekunów sprowadza się do zaspokajania potrzeb dziecka, pobudzania i ukierunkowania nowych potrzeb, z których gotowość do samokontroli i poszerzania jej zakresu jest bardzo istotna. Efektywne nauczanie, nabywanie doświadczeń zachodzi wówczas, gdy dorośli organizują określone sytuacje, uwzględniając rodzaj i zakres zainteresowań dziecka. W późnym dzieciństwie to obca osoba, jaką jest nauczyciel, staje się jedną z najważniejszych znaczących w życiu dziecka. Nauczyciel stanowi źródło kompetencji, które mają zbliżać dziecko do świata dorosłych, a szczególnie kształtować jego samoocenę. Warto tu zwrócić uwagę na wartość tych poczynań uczących, które mają charakter wsparcia, dbania o właściwe poczucie własnej wartości i rozwijanie kompetencji metapoznawczych ucznia. Zarysowane powyżej właściwości rozwojowe okresu dzieciństwa są podstawą formułowania oczekiwań wobec zachowań dziecka.

Należy ponadto zwrócić uwagę na fakt, że rozwój w okresie dzieciństwa, jak i w dalszym biegu życia, charakteryzują cechy indywidualne. Wrażliwość na te cechy dorosłych, którzy pozostają w kontakcie z dzieckiem, jest niezbędnym warunkiem realizacji postulatu jego podmiotowego traktowania. Postulat ten nie traci później na aktualności. 


\section{Przygotowanie do uczestnictwa w Eucharystii}

Rodzina jako Kościół domowy wychowanie religijne krok po kroku

Przygotowanie do uczestnictwa w Eucharystii spoczywa na rodzinie, która stanowi podstawową grupę społeczną realizującą wychowanie nowego jej członka. Rodzina religijnie zaangażowana spośród różnych aspektów wychowania realizuje również wychowanie religijne. Warunki, jakie sprzyjają temu wychowaniu, są zakotwiczone w mechanizmach rozwoju człowieka. Rytualne zachowania religijne rodziców, codziennie powtarzane, jak na przykład: czynienie znaku krzyża, krótka głośna modlitwa, tak samo jak inne codzienne czynności są źródłem naśladowania przez dziecko. Zachodzi tu proces identyfikacji z pierwszymi osobami znaczącymi, jak matka i ojciec. Stopniowo zgodnie z własną aktywnością dziecko przejawia chęć współuczestnictwa w tych działaniach. Ta wspólna modlitwa rodziców i dziecka staje się drogą do wspólnoty Kościoła powszechnego. Wspomaganie procesu przygotowania dziecka między drugim a trzecim rokiem życia do udziału we wspólnocie stanowi przekaz wiedzy religijnej (opowieści religijne, krótkie filmy, wyjaśnianie symboli religijnych) w rodzinie, domowym Kościele. Zanim dziecko zacznie stawać się uczestnikiem mszy świętej, rodzic powinien pojawić się z nim w świątyni, by zapoznać je z samym miejscem. Wymagałoby to kilku w niej wizyt, pokazania dziecku podstawowych elementów przestrzeni kościoła, ciekawie objaśnionych przez rodzica. Taką funkcję zapoznawania dzieci z miejscem odprawiania Eucharystii mogą i powinny wspierać katechetki uczące w przedszkolu. Wczesna katecheza często nie tylko uzupełnia wiedzę religijną wyniesioną z domu rodzinnego, ale stanowi jej jedyne źródło. 
Wskazane wydaje się w tym celu wykorzystanie przez katechetki obrazów religijnych, filmów, opowieści i aktywizowanie samych dzieci do własnych opowiadań i rysunków, ilustracji. Nie może zabraknąć sprawdzenia rozumienia przekazywanych treści i w razie potrzeby wprowadzania korekt.

W stosunku do małego dziecka to rodzic powinien decydować, kiedy może się ono pojawić w kościele na mszy dla dzieci. Wynika to zarówno z potencjału intelektualnego dziecka, jak i jego temperamentu oraz poziomu kontroli emocjonalno-społecznej.

Msze dla dzieci - konieczność czy możliwość?

Proces wychowania religijnego we wczesnym i średnim dzieciństwie wymaga zastąpienia oddziaływań rodziny jako Kościoła domowego oddziaływaniami „profesjonalisty” - księdza sprawującego Eucharystię. Specyfika odbioru symbolicznych treści przez dzieci oraz ich poziom rozwoju społeczno-emocjonalnego sprawiają, że tam, gdzie to możliwe, powinny być wprowadzane msze dla dzieci, które wyraźnie różniłyby się od Eucharystii sprawowanej dla dzieci starszych i dorosłych. Msza dla dzieci powinna trwać krócej ze względu na właściwości skupiania uwagi i utrzymywania zainteresowania zachodzącymi wydarzeniami, co sprowadzałoby się do: jednego tylko czytania i krótkiej homilii. Jednakże nawet krótkie kazanie musi wyjaśniać symbolikę zawartą w Ewangelii, uwzględniając poziom myślenia dzieci w tym wieku, a ksiądz podczas sprawowania Eucharystii ma być jakby komentatorem poszczególnych jej części.

Taki komentarz to jedno zdanie zapowiadające daną część mszy, a przed jej rozpoczęciem stworzenie atmosfery jakby uroczystej wizyty u kogoś, kto nas kocha. Dzieci mogą być zachęcane zarówno do spontanicznych form wyrażania radości 
z mającego nastąpić spotkania, jak i zasugerowanych podczas śpiewu pieśni religijnych. Msza dla dzieci powinna być prowadzona przez tego samego księdza co tydzień. Ta sama osoba daje dzieciom poczucie bezpieczeństwa i pozwala na tworzenie relacji ksiądz-grupa dzieci. Dla kapłana zaś stwarza warunki do coraz lepszego poznania dzieci i doskonalenia swoich poczynań.

Nie bez znaczenia są cechy, jakie posiada ksiądz sprawujący mszę świętą dla dzieci. Wydaje się, że nie tylko podstawowe przygotowanie psychologiczne i pedagogiczne do pracy z dziećmi jest tu ważne, ale posiadanie określonych cech osobowości do niej predysponujących. Do podstawowych należy otwartość na kontakt z drugim człowiekiem i sposób nawiązywania, podtrzymywania kontaktu. Życzliwe nastawienie wobec dzieci przejawia się w zachowaniach niewerbalnych i werbalnych księdza, zanim zacznie on sprawować Eucharystię i podczas głoszenia homilii. Każdy człowiek dorosły ma określony poziom kompetencji komunikacyjnej, lecz od takich osób, które stają się wzorem dla innych (rodzic, nauczyciel, ksiądz), pożądany jest jej wysoki poziom. Decydująca, w przypadku kapłana głoszącego homilię, jest poprawność wymowy, struktury gramatycznej wypowiedzi, treść przekazana w sposób spójny logicznie z uwzględnieniem możliwości słuchaczy, przy jednoczesnym zachowaniu ważnych treści teologicznych. Obok wspomnianych już wymogów - długość, język, sposób wyjaśniania symboli - pozostaje forma kazania. Można wzbogacać treść wypowiedzi odwołującej się do Ewangelii pomocami dydaktycznymi, jak obrazy, przedmioty, rysunki, pamiętając, by forma nie przerosła lub nawet nie usunęła istoty treści. Kazanie dla dzieci może też przybrać postać dialogu ze słuchaczami. Dialogiem kieruje ksiądz, pamiętając, jak ważne jest takie formułowanie pytań czy poleceń, by stymulować kreatywność dzieci i prowokować 
do ujawnienia ich sposobu odczytania treści ewangelii. Każda wypowiedź dziecka jest świadectwem jego możliwości pojmowania i winna być doceniona jako aktywny udział, a jej treść wykorzystana przez księdza jako informacja do dalszej rozmowy. Warto formułować otwarte pytania, a nie zamknięte, wystrzegać się podpowiedzi podających pierwszą sylabę pożądanego słowa, co często prowadzi do humorystycznych odpowiedzi, niemających nic wspólnego z pytaniem. Jeśli w zamyśle kierującego dialogiem księdza niezbędne jest zapamiętanie przez dzieci jakiejś nazwy - miejscowości, imienia, a dzieci jej nie podają, pozostaje tylko ją wymienić, a potem powtórzyć. Sądzę, że bez zdolności uważnego słuchania trudno będzie prowadzić dialog z dziećmi, a potem z młodzieżą. Sprawowanie mszy dla dzieci wymaga ponadto umiejętności stawiania dzieciom granic. Nie wystarczy wyznaczyć granic zachowania przed mszą, ale w jej trakcie należy stwarzać ku temu odpowiednie warunki, skupiając uwagę dzieci na określonym obrzędzie liturgii eucharystycznej. Taką funkcję pełni przywołanie ich przed ołtarz, podnoszenie w górę rąk podczas modlitwy Pańskiej, klękanie, prośba o przejście do rodziców na czas udzielania Komunii itp.

\section{Udział elementów zabawowych w mszy dla dzieci}

Uważam, że msza dla dzieci nie powinna być zorganizowaną zabawą. Naturalnie dzieci, zachęcane przez księdza, mogą na różne sposoby wyrażać swoją radość ze spotkania z Bogiem - czy to określoną formą ruchu, klaskaniem, czy też animując słowa pieśni religijnych. Elementy uprzystępniania treści obrzędów mszy świętej, które mogą być pokrewne zabawie ruchowej bądź receptywnej, nie czynią jednak zachowania dzieci w kościele zabawą. Przyjście do świątyni nie ma kojarzyć 
się dziecku z zabawą, ale z czymś wzniosłym, a jednocześnie ciekawym, bo tajemniczym. Tajemnica obecności Boga, choć nie jest widziany, motywuje do pozostania i oczekiwania, w jaki sposób się ujawni. Egocentryczne cechy myślenia dziecka, jego wyobraźnia, która bez przeszkód oscyluje między fikcją a rzeczywistością, sprzyjają percepcji i przeżywaniu sacrum, tendencji do transcendencji. To, co dorosłym wydaje się nie do objęcia rozumem, dziecko przyjmuje jako fakt, nie ma potrzeby szukania argumentów. Taka poznawcza postawa, właściwa dla dzieci w wieku przedszkolnym, sprzyja zainteresowaniu tym, co bardziej odległe od zdarzeń rzeczywistych. Dlatego dzieci tak chętnie słuchają bajek i baśni, legend, w których tajemniczy nastrój towarzyszy stawaniu się możliwym tego, co było niemożliwe. Jeśli natomiast, zgodnie z tezą, że podstawową formą aktywności dziecka jest zabawa, będziemy na różne sposoby uatrakcyjniać zabawowo mszę, stworzy to zagrożenie uczynienia profanum z sacrum. Dzieci będą bowiem oczekiwać atrakcji, a tajemnica przeistoczenia hostii w ciało Jezusa Chrystusa i wina w krew nie będzie wiodącym źródłem przeżyć. W tym wieku magiczne, intuicyjne myślenie i cechy wyobraźni czynią to przeżycie naturalnym pod warunkiem, że wcześniej i w trakcie mszy dziecko otrzymuje informacje o akcie przeistoczenia. Jeśli dziecko będzie miało potrzebę odtworzenia tego, co było jego udziałem podczas mszy, uczyni to, bawiąc się w „odprawianie mszy" w domu czy przedszkolu. Świadczą o tym zapisy zabaw dzieci Władysława Dynera ${ }^{2}$ czy obserwacje Stefana Szumana ${ }^{3}$. W ten sposób zabawa stanie się areną przeżywania tego, co dziecko odebrało w realnej rzeczywistości.

\footnotetext{
W. Dyner, Zabawy tematyczne dzieci w domu i przedszkolu, Wrocław 1971.

S. Szuman, Psychologia wychowawcza wieku dziecięcego, Warszawa 1947; S. Szuman, Psychologia dziecka w wieku przedszkolnym, Warszawa 1960.
} 


\section{Msza dla dzieci wymaga obecności ich rodziców}

Taki postulat bezpośrednio wiąże się z faktem, że msza jest sprawowana i przeżywana we wspólnocie. Młodszy przedszkolak nie zawsze potrafi włączyć się w grupę rówieśników, stając się jej członkiem. W miejscu, jakim jest świątynia, ten proces zapośredniczają rodzice. Szczególnie ważna jest tu osoba ojca i jego zachowanie, ponieważ następuje przenoszenie cech ojca na obraz Boga - wertykalne transcendowanie ${ }^{4}$. Zachowania całej rodziny, a przede wszystkim rodziców jako osób znaczących, sprzyjają procesowi transcendencji horyzontalnej, czyli przenoszeniu cech zachowań rodziny na całą wspólnotę wiernych, a więc Kościół. Przystępowanie do Komunii rodziców, trzymających za rękę dziecko, przybliża je tak w dosłownym, jak i przenośnym znaczeniu do Boga. Jeśli takie zachowania się powtarzają, tendencja do ich naśladownictwa na wzór rodzica się utrwala. Ponadto czynienie znaku krzyża przez księdza na czole dziecka, którego rodzic przyjmuje Komunię, sprawia, że i ono zaczyna czuć się członkiem wspólnoty w najważniejszym momencie sprawowania Eucharystii ${ }^{5}$.

Należy zwrócić uwagę na rolę rodziców w podjęciu decyzji o gotowości uczestniczenia dziecka we mszy. Cechy indywidualne, szczególnie związane z temperamentem, jak nadpobudliwość ruchowa, poznawcza i/lub emocjonalna, a także osobowościowe (lękliwość, nieśmiałość), sprawiają, że takie decyzje nie są łatwe, a co gorsza - zdarzają się niewłaściwe. Problemem staje się nie tylko fakt, że dzieci o specjalnych potrzebach przeszkadzają w kościele innym dzieciom i dorosłym, ale to, że karcące reakcje dorosłych mogą na długi czas uczynić dla nich

4 M. Ligęza, Postawy religijne rodziców w opinii dzieci, [w:] Odpowiedzialne rodzicielstwo wobec wyzwań XXI wieku, red. M. Duda, Kraków 2010, s. 122-147.

5 Cz. Walesa, Rozwój religijności człowieka, t. 1: Dziecko, Lublin 2005. 
kościół miejscem kojarzonym z nieprzyjemnymi doznaniami. Warto więc prowadzić msze dla dzieci o specyficznych potrzebach z udziałem co najmniej dwu księży, odpowiednio przygotowanych do ich prowadzenia (studia z zakresu psychologii, a szczególnie pedagogiki specjalnej).

Dzieci w młodszym wieku szkolnym, zwłaszcza te, które brały wcześniej udział w mszach dla dzieci, powinny stanowić wspólnotę spotykającą się na mszach z homilią do nich skierowaną. Kazania nadal wymagają objaśnienia symboliki Ewangelii, ale już na poziomie myślenia operacyjnego odbiorców. Tu najbardziej wskazana byłaby dialogowa forma przekazu. Omówione powyżej pożądane cechy księdza pozostają nadal aktualne, są bowiem uniwersalnymi właściwościami osób, których zadaniem jest skuteczne porozumiewanie się $\mathrm{z}$ innymi. Ponadto ksiądz, traktowany przez dzieci w tym wieku jako nauczyciel, może stać się autorytetem, co dla procesu wychowania religijnego jest bardzo ważne.

Psycholog rozwojowy musi jeszcze zaakcentować powiązanie szans i zagrożeń liturgicznego przepowiadania do dzieci z całą perspektywą innych wielorakich oddziaływań na ich rozwój duchowy. We wczesnym dzieciństwie rodzina pełni rolę priorytetową jako Kościół domowy, stąd nasuwa się sugestia o konieczności porozumiewania się z rodzicami i zsynchronizowania oddziaływań księży i rodziców. Wymaga to $\mathrm{w}$ wielu przypadkach kreatywnych form edukacji religijnej samych rodziców, a przede wszystkim wzbudzania ich motywacji do współdziałania. W średnim dzieciństwie należałoby objąć współpracą także katechetów, aby powiązać treści przekazywane w katechezach i w homiliach. Późne dzieciństwo wymaga ponadto uwzględnienia grupy rówieśniczej (schola, grupy ministrantów i ich sympatyków), czemu sprzyjałoby zorganizowanie ciekawego dla dzieci sposobu spędzania wolnego 
czasu na zajęciach sportowych, wycieczkach itp. Wydaje się oczywiste, że takie zadania nie spoczywałyby tylko na księżach prowadzacych msze dla dzieci, ale powinni mieć oni w tym znaczący udział. Bardzo ważne jest w przygotowywaniu homilii do dzieci uwzględnienie aspektów biblijnych, liturgicznych, językoznawczych, pedagogicznych i psychologicznych. Pamiętać jednak trzeba, że najlepiej przygotowane homilie nie wypełnią całego procesu edukacji i wychowania religijnego. Wsparcie liturgicznego przepowiadania do dzieci innymi formami oddziaływań, zgodnych z nauką Kościoła, a jednocześnie innowacyjnie nawiązujących do rzeczywistości XXI w., stanowić winno przesłanie zmian w sposobie wychowania religijnego młodego pokolenia. Przede wszystkim ten współczesny świat, z różnych przyczyn, wymaga większego niż dawniej wsparcia rodziny, jako szkoły wiary, która przygotowuje wspólną modlitwą do obrzędów liturgicznych. Bez tego wsparcia wychowanie religijne może się stać „kolosem bez nóg”.

\section{Bibliografia}

Dyner W., Zabawy tematyczne dzieci w domu i przedszkolu, Wrocław 1971.

Ligęza M., Postawy religijne rodziców w opinii dzieci, [w:] Odpowiedzialne rodzicielstwo wobec wyzwań XXI wieku, red. M. Duda, Kraków 2010, s. 122-147.

Szuman S., Psychologia wychowawcza wieku dziecięcego, Warszawa 1947.

Szuman S., Psychologia dziecka w wieku przedszkolnym, Warszawa 1960.

Walesa Cz., Rozwój religijności człowieka, t. 1: Dziecko, Lublin 2005. 